\title{
Potensi kerusakan lingkungan perairan laut akibat pengoperasian alat tangkap sondong di kecamatan Concong Kabupaten Indragiri Hilir
}

\author{
Gusti Indra $^{1}$, Nofrizal ${ }^{2}$, Viktor Amrifo ${ }^{3}$ \\ 1,2,3 Pascasarjana Ilmu Lingkungan Program Pascasarjana Universitas Riau
}

\begin{abstract}
Based on the research that has been carried out, the extent of potential damage to marine waters due to the operation of the sondong is directly proportional to the length of the operation time, the size of the sondong, the sweep length and the number of back and forth fishing gear. The longer the operating time, the larger the fishing gear size, the wider the sweep area and the greater the number of fishing gear settings (back and forth), the greater the potential for damage to marine waters. The catch consists of 37 species (including garbage), 2 types of main catch species (maincatch), 15 types of bycatch species and 20 species (including waste) from discard. Percentage of catch based on number (head) for main catch is $38 \%$, bycatch $11 \%$ and bycatch $51 \%$. Percentage of catch based on weight (kg) is for main catch $22 \%$, bycatch $6 \%$ and waste catch $72 \%$. The captured waste that is not valued is thrown away both alive and dead will become waste, this has triggered serious conservation problems due to the waste of valuable natural resources and causes populations of species to be endangered and even extinct. It can be said that there are no social, economic and conflict impacts that arise in the aquatic environment due to the operation of the fishing gear. Socially, the operation of the sondong fishing gear in the waters of the research location is acceptable, the decrease in fishermen's income and the (economic) catch in general is not due to the operation of the sondong fishing gear.
\end{abstract}

Keywords: Sondong; Main catch; Bycatch; Discard

Tingkat pemanfaatan potensi sumberdaya perikanan dapat dijadikan suatu indikator perkembangan dari suatu kegiatan penangkapan yang telah dilakukan di perairan dan sekaligus juga menjadi suatu pedoman dalam rangka pengelolaan perikanan tangkap berkelanjutan tanpa merusak kelestarian sumberdaya. Masalah belum optimalnya produksi dalam kegiatan perikanan tangkap dapat diperkirakan tiga hal antara lain : pertama; rendahnya sumberdaya manusia nelayan dan ilmu pengetahuan serta teknologi penangkapan ikan, kedua; ketimpangan pemanfaatan sumberdaya ikan di kawasan tertentu, ketiga; terejadinya kerusakan lingkungan ekosistem laut seperti mangrove, terumbu karang dan padang lamun yang merupakan habitat ikan dan organisme laut lainnya berpijah, mencari makan atau membesarkan diri.

Untuk melindungi sumberdaya ikan dan lingkungan perairan laut adalah pengembangan alat tangkap ramah lingkungan sesuai arahan Code of Conduct for Responsible Fisheries. Secara umum dapat dikatakan bahwa teknologi penangkapan ramah lingkungan adalah teknologi penangkapan yang dapat menangkap ikan atau biota laut lainnya secara selektif dengan dampak minimum terhadap kelangsungan hidup (survivalbility) ikan-ikan yang lolos dari proses penangkapan dan terhadap lingkungan perairan (Mardjudo, 2011)

Food Agriculture Organization (FAO, 1995) mengeluarkan suatu tata cara kegiatan penangkapan ikan yang bertanggung jawab (Code of Conduct for Responsible Fisheries - CCRF). Dalam CCRF ini FAO menetapkan serangkaian kriteria bagi teknologi penangkapan ikan ramah lingkungan. Sembilan kriteria tersebut yaitu : 1) alat tangkap harus memiliki selektivitas yang tinggi; 2) alat tangkap yang digunakan tidak merusak habitat; 3) alat tangkap tidak membahayakan nelayan; 4) menghasilkan ikan yang bermutu baik; 5) produk ikan yang dihasilkan tidak membahayakan kesehatan konsumen; 6) hasil tangkapan bycatch (sampingan) dan discard (buangan) seminimal mungkin; 7) alat tangkap yang digunakan harus memberikan dampak minimum terhadap keanekaragaman sumberdaya hayati (biodiversity); 8) tidak menangkap jenis yang dilindungi undang-undang atau terancam punah; dan 9) alat tangkap tersebut dapat diterima secara sosial.

\section{METODA PENELITIAN}

Penelitian dilaksanakan di Kecamatan Concong Kabupaten Indragiri Hilir Provinsi Riau. Waktu penelitian dilaksanakan pada bulan Februari 2019 sampai April 2019. Metode yang digunakan dalam penelitian ini adalah metode survei. Menurut Ghozali (2005), metode survei yaitu dengan melakukan pengamatan langsung terhadap objek penelitian berupa kondisi terkini. Selanjutnya Sugiyono (2012) menyatakan metode survei adalah untuk memberikan gambaran secara detail tentang latar belakang, sifatsifat, serta karakter yang khas dari kasus atau kejadian. 


\section{ZONA}

Jurnal Lingkungan

Volume 4, No 2, Oktober 2019, p. 83-94

ISSN : 2502-6496 (Print) http://zona.pelantarpress.co.id

Populasi pada penelitian ini adalah semua nelayan alat tangkap sondong di Kecamatan Concong Kabupaten Indragiri Hilir. Sampel penelitian adalah 10 persen dari seluruh nelayan sondong. Informasi dan data untuk mengetahui dampak sosial dan ekonomi masyarakat nelayan ditetapkan 5 orang responden dari alat tangkap lainnya. Informasi dan data pendukung diperoleh dari kepala UPT Dinas Perikanan dan Kelautan Kecamatan Concong serta dari 5 orang Kepala Desa di Kecamatan Concong dan 5 orang tokoh masyarakat dari setiap desa satu orang. Penetapan tokoh masyarakat sebagai responden didasarkan pertimbangan dan saran Kepala Desa dan informasi dari masyarakat desa.

\section{HASIL DAN PEMBAHASAN}

\section{Potensi Kerusakan Dasar Perairan Akibat Pengoperasian Sondong}

Nelayan alat tangkap sondong yang dijadikan sampel dalam penelitian ini adalah sebanyak 15 orang dengan ukuran alat tangkap (sondong)

Tabel 1. Hasil Pengukuran Alat Tangkap Sondong

\begin{tabular}{ccccccc}
\hline No. & Sondong & $\begin{array}{c}\text { Panjang } \\
\text { (meter) }\end{array}$ & $\begin{array}{c}\text { Lebar } \\
\text { (meter) }\end{array}$ & $\begin{array}{c}\text { Jumlah } \\
\text { Hilir/Mudik } \\
\text { (setting) }\end{array}$ & $\begin{array}{c}\text { Panjang } \\
\text { Sapuan } \\
\text { (meter) }\end{array}$ & $\begin{array}{c}\text { Lama Operasi } \\
\text { Per Hari } \\
\text { (Jam) }\end{array}$ \\
\hline 1 & I & 12 & 9 & 16 & 8.000 & 8 \\
2 & II & 12 & 9 & 9 & 20.700 & 9 \\
3 & III & 15 & 6 & 8 & 14.400 & 8 \\
4 & IV & 15 & 8 & 11 & 9.900 & 8,25 \\
5 & V & 12 & 6 & 8 & 16.000 & 8 \\
6 & VI & 15 & 9 & 10 & 18.000 & 10 \\
7 & VII & 15 & 8,6 & 12 & 13.200 & 6 \\
8 & VIII & 13,8 & 7,7 & 12 & 12.000 & 6 \\
9 & IX & 14,5 & 8 & 15 & 15.500 & 7,5 \\
10 & X & 12 & 6 & 10 & 17.600 & 8 \\
11 & XI & 12 & 8 & 8 & 12.000 & 8,3 \\
12 & XII & 15 & 6 & 10 & 8.000 & 8 \\
13 & XIII & 12 & 6 & 10 & 10.000 & 6,6 \\
14 & XIV & 12 & 7,5 & 10 & 197.300 & 119.95 \\
15 & XV & 14 & 8,5 & 157 & & \\
\hline Jumlah & & 201,3 & 113,3 & & & \\
\hline
\end{tabular}

Ukuran terpanjang dari alat tangkap sondong dalam penelitian ini adalah 15 meter dengan ukuran terlebar adalah 9 meter. Panjang rata-rata alat tangkap yang digunakan adalah 13,42 meter dan lebar ratarata adalah 7,55 meter, jumlah rata-rata setting (hilir/mudik) 10,46 kali dalam sekali beroperasi, panjang sapuan sondong rata-rata 13.153 meter dan rata-rata waktu operasional yang digunakan 7,99 jam dalam satu hari.

Luas Area Potensi Kerusakan Lingkungan Perairan

Untuk perhitungan luas sapuan sondong dalam penelitian ini

Tabel 2. Hasil Perhitungan Luas Sapuan Sondong

\begin{tabular}{ccccr}
\hline No & Sondong & $\begin{array}{c}\text { Panjang Sapuan } \\
\text { Sondong } \\
\text { (meter) }\end{array}$ & $\begin{array}{c}\text { Lebar Mulut } \\
\text { Sondong } \\
(\text { meter })\end{array}$ & $\begin{array}{c}\text { Luas } \\
\text { Sapuan Sondong } \\
\left(\text { meter }^{2}\right)\end{array}$ \\
\hline 1 & & 8.000 & 9 & 72.000 \\
2 & I & 20.700 & 9 & 186.300 \\
3 & II & 14.400 & 6 & 86.400 \\
4 & III & 9.900 & 8 & 79.200 \\
5 & IV & 16.000 & 6 & 16.000 \\
6 & V & 18.000 & 9 & 113.000 \\
7 & VI & 13.200 & 8,6 & 92.400 \\
8 & VII & 12.000 & 7,7 & 84.000 \\
9 & VIII & 10.500 & 8 & 90.000 \\
10 & IX & 15.000 & 6 & 72.000 \\
11 & X & 17.600 & 8 & 72.000 \\
12 & XI & 12.000 & 6 & 60000 \\
13 & XII & 12.000 & 6 & 85.000 \\
14 & XIII & 8.000 & 7,5 & 1.491 .620 \\
15 & XV & 10.000 & 8,5 & 113,3 \\
\hline Jumlah & & 197.300 & & \\
\hline
\end{tabular}




\section{ZONA}

Jurnal Lingkungan

Volume 4, No 2, Oktober 2019, p. 83-94

ISSN : 2502-6496 (Print)

Luas sapuan sondong masing-masing sampel

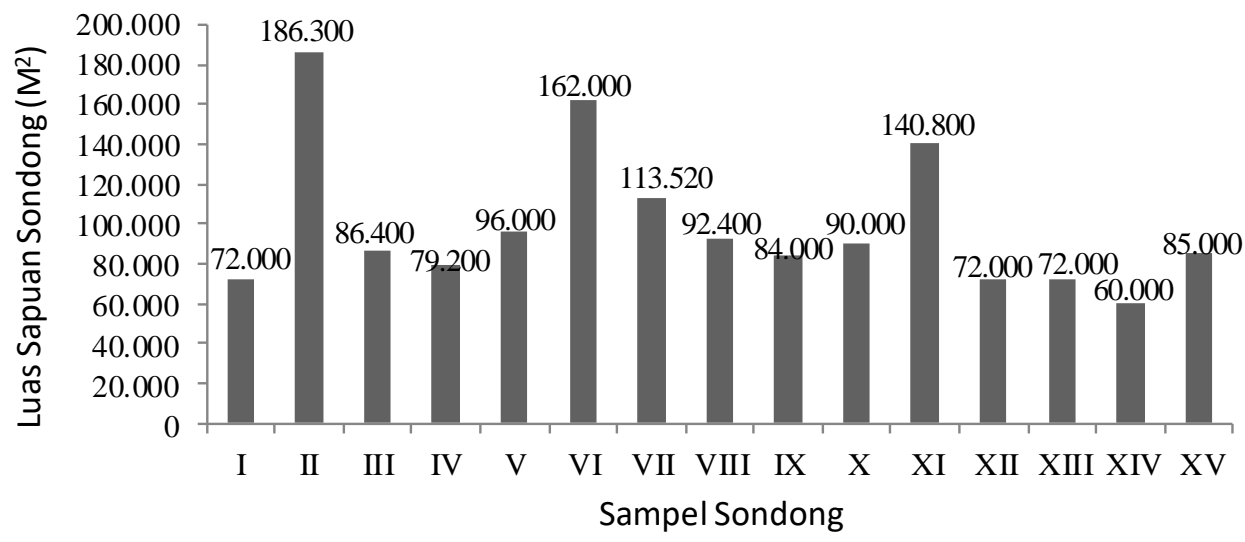

Gambar 1. Rata-rata luas sapuan sondong dari sampel yang diambil selama penelitian adalah $99.441,33$ $\mathrm{m}^{2}$, nilai yang terluas adalah $186.300 \mathrm{~m}^{2}$ dan yang terendah adalah $60.000 \mathrm{~m}^{2}$

Tabel 3. Luas Potensi Kerusakan Dasar Perairan

\begin{tabular}{ccrcr} 
No & Sondong & $\begin{array}{c}\text { Luas } \\
\text { Sapuan Sondong } \\
\left(\text { (meter }^{2}\right)\end{array}$ & $\begin{array}{c}\text { Jumlah Setting } \\
\text { Hilir-Mudik } \\
(\text { kali) }\end{array}$ & $\begin{array}{c}\text { Luas } \\
\text { Potensi Kerusakan } \\
\left(\text { meter }^{2}\right)\end{array}$ \\
\hline 1 & & 72.000 & 16 & 1.152 .000 \\
2 & I & 186.300 & 9 & 1.676 .700 \\
3 & II & 86.400 & 8 & 691.200 \\
4 & III & 79.200 & 11 & 871.200 \\
5 & IV & 96.000 & 8 & 768.000 \\
6 & VI & 162.000 & 10 & 1.620 .000 \\
7 & VI & 113.520 & 12 & 1.362 .240 \\
8 & VIII & 92.400 & 12 & 1.108 .800 \\
9 & IX & 84.000 & 15 & 900.000 \\
10 & X & 90.000 & 10 & 1.126 .400 \\
11 & XI & 140.800 & 8 & 720.000 \\
12 & XII & 72.000 & 10 & 576.000 \\
13 & XIII & 72.000 & 8 & 800.000 \\
14 & XIV & 60.000 & 10 & 850.000 \\
15 & XV & 85.000 & 10 & 15.282 .540 \\
\hline
\end{tabular}

Hasil perhitungan total luas potensi kerusakan dasar perairan dari penelitian yang dilakukan adalah 15.282.540 $\mathrm{m}^{2}$, rata-rata luas potensi kerusakan dasar perairan adalah $101.836 \mathrm{~m}^{2}$. Perhitungan luas terbesar adalah $1.676 .700 \mathrm{~m}^{2}$ dan yang terkecil adalah $576.000 \mathrm{~m}^{2}$. Hal ini menunjukkan bahwa hasil perhitungan luas potensi kerusakan dasar perairan berbanding lurus dengan lamanya waktu operasi, ukuran sondong, panjang sapuan dan jumlah hilir-mudik alat tangkap sondong. Semakin lama waktu operasi, semakin besar ukuran alat tangkap, semakin banyak luas sapuan dan semakin banyak jumlah setting (hilir-mudik) alat tangkap, semakin besar pula potensi kerusakan dasar perairan.

\section{Parameter Kualitas Perairan}

Parameter kualitas perairan yang diukur meliputi parameter fisika dan kimia perairan pada kawasan sapuan sondong (fishing ground) sebelum dan sesudah sondong dioperasikan yang didorong dengan perahu motor dalam penelitian ini 
Tabel 4. Hasil Pengukuran Rata-Rata Parameter Kualitas Perairan Sebelum dan Sesudah Alat Tangkap Sondong Dioperasikan Selama Penelitian

\begin{tabular}{lllll}
\multicolumn{1}{c}{ Parameter } & Satuan & Sebelum & Sesudah & $\begin{array}{l}\text { Perubahan Setelah } \\
\text { Sondong } \\
\text { Beroperasi }\end{array}$ \\
\hline Parameter Fisika & & & & \\
Suhu & ${ }^{\circ} \mathrm{C}$ & 27,66 & 30,26 & $+2,60$ \\
Kecerahan & $\mathrm{cm}$ & 58,93 & 51,60 & $-7,33$ \\
Kekeruhan & NTU & 8,60 & 10,68 & $+2,08$ \\
Kecepatan Arus & m/detik & 0,29 & 0,24 & $-0,05$ \\
Kedalaman & meter & 2,77 & 2,34 & $-0,43$ \\
TSS & mg/1 & 34,60 & 37,13 & $+2,53$ \\
& & & & \\
Parameter Kimia & & & & \\
pH & - & 7,46 & 7,58 & $+0,12$ \\
Salinitas & ooo & 33,53 & 33,66 & $+0,13$ \\
DO & mg/1 & 6,33 & 5,85 & $-0,48$ \\
\hline
\end{tabular}

\section{Komposisi Hasil Tangkapan Utama, Sampingan dan Buangan}

Analisis komposisi hasil tangkapan dengan melihat jenis organisme akuatik yang tertangkap, menghitung jumlah jenis dan spesies serta mendeskripsikan dari seluruh hasil tangkapan dengan menghitung jumlah jenis organisme akuatik yang masuk ke dalam kantong sondong, menghitung berat masing-masing jenis dan spesies dan mendeskripsikan seluruh hasil tangkapan.

Tabel 5. Jenis organisme akuatik yang tertangkap selama penelitian Jenis organisme akuatik yang tertangkap

\begin{tabular}{clc}
\hline No & \multicolumn{1}{c}{ Nama Lokal/Daerah } & Nama Latin/Ilmiah \\
\hline 1 & Udang Tiger/Windu & Penaeus monodon \\
2 & Udang Kuning/Jerbung & Fenneropenaeus marguiensis \\
3 & Ikan Gelama & Nibea soldado \\
4 & Ikan Selidah & Cynoglossus lingua \\
5 & Udang Nenek/Mantis & Lysiosquila maculata \\
6 & Ikan Duri & Hexanematichthys sagor \\
7 & Ikan Bilis & Engraulis japonicus \\
8 & Ikan Lomek & Ateoleopus japonicus \\
9 & Ikan Biang & Ilisha elongata \\
10 & Ikan Gonjeng & Thryssa mystax \\
11 & Ikan Senangin Pinang & Eleutheronema tetradactylum \\
12 & Ikan Timah & Aplocheilus panchax \\
13 & Kerang & Tegillarca granosa \\
14 & Ikan Bawal & Pampus argenteus \\
15 & Ikan Tamban & Spratelloides gracilis \\
16 & Blankas & Linulidae sp \\
17 & Ketam Kecil Laut & Scylla sp \\
18 & Anak Lobster & Nephropidae sp \\
19 & Ikan Buntal & Tetraodon miurus \\
20 & Lepu & Pterois volitans \\
21 & Ikan Senyenjeng & Ateoleopus sp \\
22 & Ikan Baji & Platycephalus indicus \\
23 & Udang Duri & Panulirus versicolor \\
24 & Siput Duri & Murex tribulus \\
25 & Anak Ikan Pari & Dasyatidae sp \\
26 & Laba-Laba Laut & Pantopoda sp \\
27 & Umang-Umang Lumpur & Paguroidea sp \\
28 & Bronot/Timun Laut & Holothuroidea sp \\
29 & Ketam Putih & Scylla sp \\
30 & Siput Laut & Gastropoda sp \\
31 & Anak Ikan Alu-Alu & Sphyraena sp \\
32 & Ikan Kitang & Scatophagus argus \\
33 & Ikan Kekek & Leiognatus equulus \\
34 & Ikan Kurau & Eleutheronema tetradactylum \\
35 & Ikan Malung & Muraenesox cinereus \\
36 & Anak Hiu Kucing & Scyliorhinidae sp \\
\hline & & \\
& &
\end{tabular}




\section{ZONA}

Jurnal Lingkungan

ISSN : 2502-6496 (Print)

Volume 4, No 2, Oktober 2019, p. 83-94

http://zona.pelantarpress.co.id

Total jenis organisme akuatik hasil tangkapan yang teridentifikasi selama penelitian terdiri dari 36 spesies dengan beberapa jenis spesies udang, ketam/kepiting (crustacea), ikan (fishes), siput/kerang (mollusca).

\section{Hasil Tangkapan Utama}

Tabel 6. Hasil tangkapan utama (maincatch) alat tangkap sondong

\begin{tabular}{ccc}
\hline No & Nama Lokal/Daerah & Nama Latin/Ilmiah \\
\hline 1 & Udang Tiger/Windu & Penaeus monodon \\
2 & Udang Kuning/Jerbung & Fenneropenaeus marguiensis \\
\hline
\end{tabular}

Hasil tangkapan utama dari alat tangkap sondong adalah udang. Total jenis hasil tangkapan utama selama penelitian terdiri dari 2 spesies yaitu Udang Tiger/Windu (Penaeus monodon) dan Udang Kuning/Jerbung (Fenneropenaeus marguiensis). Hal ini didukung oleh pernyataan (Megawati et al, 2016) yaitu alat tangkap sondong merupakan alat tangkap yang target utama penangkapannya adalah udang. Dalam pengoperasian alat tangkap sondong, hasil tangkapan tidak hanya target utama tetapi masih ada jenis ikan lainya yang tertangkap.

Hasil perhitungan kepadatan relatif hasil tangkapan utama (maincatch) atau HTU selama penelitian untuk udang Tiger/Windu adalah 6.193 ekor dengan persentase 50,24\%, dan untuk udang Kuning/Jerbung adalah 6.135 ekor dengan persentase $49,76 \%$ dari total jumlah individu seluruh jenis adalah 12.328 ekor Kepadatan relatif hasil tangkapan utama

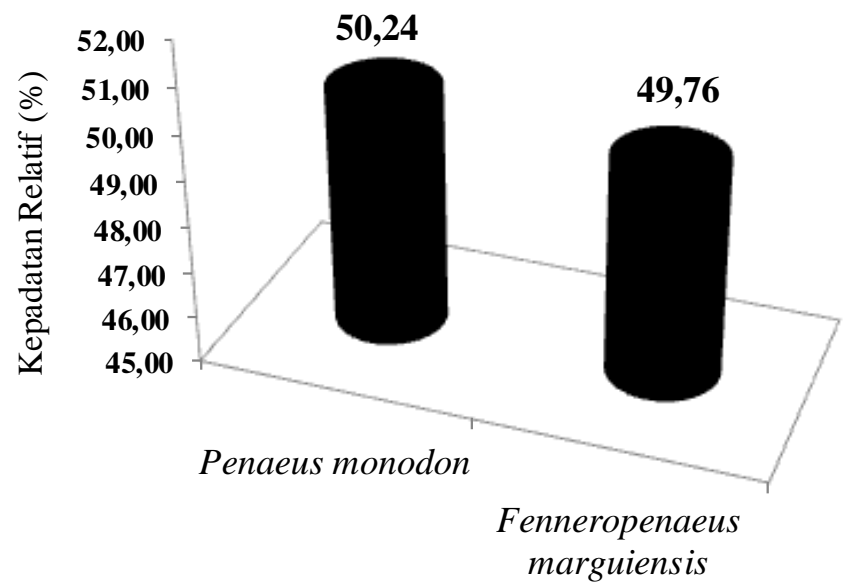

Gambar 2. Hasil perhitungan kepadatan relatif hasil tangkapan utama (maincatch) atau HTU selama penelitian untuk udang Tiger/Windu

\section{Hasil Tangkapan Sampingan}

Selain dari hasil tangkapan utamanya yaitu udang, pada saat alat tangkap sondong dioperasikan banyak juga spesies lain yang masuk kedalam kantong sondong yang tidak merupakan target atau sasaran tetapi masih bernilai ekonomis dan masih bisa dimanfaatkan oleh nelayan yang disebut dengan hasil tangkapan sampingan. Sesuai dengan pernyataan Rainaldi et al (2017) bahwa hasil tangkapan sampingan adalah bagian dari hasil tangkapan yang terdiri dari organisme laut yang bukan merupakan target penangkapan utama. Jenis hasil tangkapan sampingan selama penelitian total jenis hasil tangkapan sampingan selama penelitian terdiri dari 15 spesies yaitu beberapa jenis ikan, crustacea dan mollusca. 


\section{ZONA}

Jurnal Lingkungan

ISSN : 2502-6496 (Print)

Volume 4, No 2, Oktober 2019, p. 83-94 http://zona.pelantarpress.co.id

Tabel 7. Jenis Hasil Tangkapan Sampingan (bycatch) alat tangkap sondong

\begin{tabular}{llc}
\hline No & \multicolumn{1}{c}{ Nama Lokal/Daerah } & Nama Latin/Ilmiah \\
\hline 1 & Ikan Gelama & Nibea soldado \\
2 & Ikan Selidah & Cynoglossus lingua \\
3 & Udang Nenek/Mantis & Lysiosquila maculata \\
4 & Ikan Duri & Hexanematichthys sagor \\
5 & Ikan Bilis & Engraulis japonicus \\
6 & Ikan Lomek & Ateoleopus japonicus \\
7 & Ikan Biang & Ilisha elongata \\
8 & Ikan Bulu Ayam & Thryssa mystax \\
9 & Ikan Senangin Pinang & Eleutheronema tetradactylum \\
10 & Ikan Timah & Aplocheilus panchax \\
11 & Kerang & Tegillarca granosa \\
12 & Ikan Bawal & Pampus argenteus \\
13 & Ikan Tamban & Spratelloides gracilis \\
14 & Ikan Kurau & Eleutheronema tetradactylum \\
15 & Ikan Malung & Muraenesox cinereus \\
\hline
\end{tabular}

Kepadatan relatif hasil tangkapan sampingan (bycatch) atau HTS selama penelitian untuk ikan gelama (Nibea soldado) 195 ekor dengan persentase 5,65\%, ikan selidah (Cynoglossus lingua) 138 ekor dengan persentase 4,00\%, udang nenek/mantis (Lysiosquila maculata) 62 ekor dengan persentase 1,80\%, ikan duri (Hexanematichthys sagor) 22 ekor dengan persentase 0,64\%, ikan bilis (Engraulis japonicus) 1005 ekor dengan persentase 29,11\%, ikan lomek (Ateoleopus japonicus) 306 ekor dengan persentase 8,86\%, ikan biang (Ilisha elongata) 66 ekor dengan persentase 1,91\%, ikan bulu ayam (Thryssa mystax) 623 ekor dengan persentase $18,04 \%$, ikan senangin pinang (Eleutheronema tetradactylum) 53 ekor dengan persentase 1,53\%, ikan timah (Aplocheilus panchax) 56 ekor dengan persentase 1,62\%, kerang (Tegillarca granosa) 250 butir dengan persentase 7,24\%, ikan bawal (Pampus argenteus) 90 ekor dengan persentase 2,61\%, ikan tamban (Spratelloides gracilis) 525 ekor dengan persentase 15,20\%, ikan kurau (Eleutheronema tetradactylum) 29 ekor dengan persentase $0,84 \%$, ikan malung (Muraenesox cinereus) 33 ekor dengan persentase $0,96 \%$ dari total seluruh jenis spesies 3.453 ekor

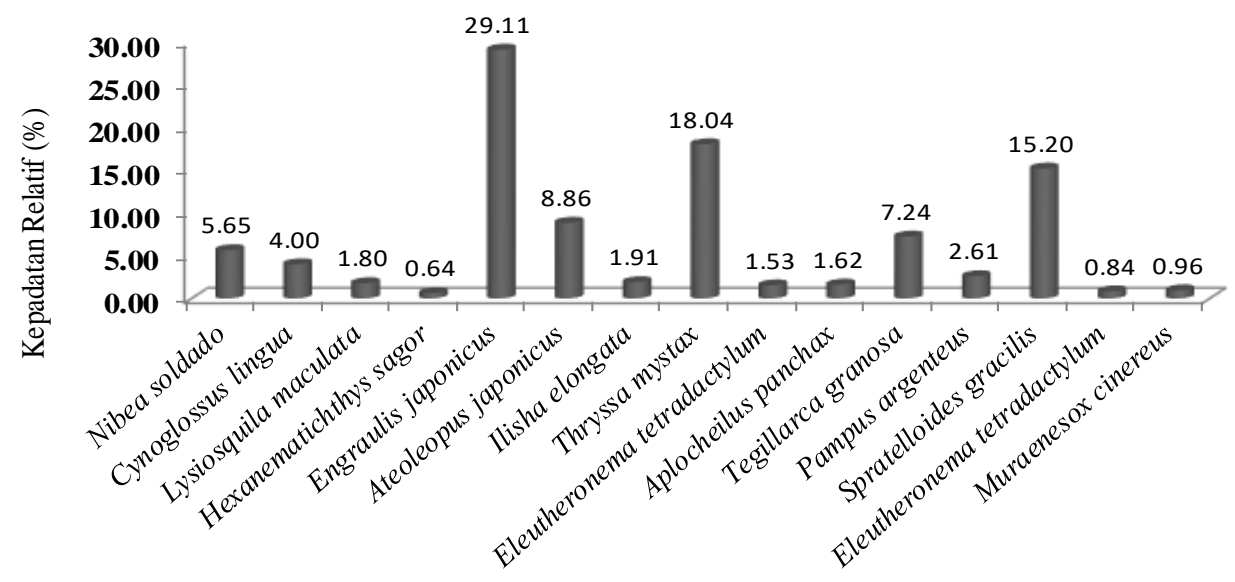

Gambar 3. Kepadatan relatif hasil tangkapan sampingan (maincatch) atau HTS

Jumlah hasil tangkapan sampingan yang diperoleh selama penelitian sebanyak lima belas spesies, spesies ikan yang mendominasi adalah ikan bilis (Engraulis japonicus) dengan persentase tertinggi yaitu $29,11 \%$ dengan jumlah spesies 1005 ekor dan spesies yang terendah persentasenya adalah ikan duri (Hexanematichthys sagor) yaitu $0,64 \%$ dengan jumlah spesies 22 ekor, jumlah total seluruh jenis spesies hasil tangkapan sampingan 3.453 ekor.

\section{Hasil Tangkapan Buangan}

Hasil tangkapan yang dibuang selama penelitian dari total seluruh jenis hasil tangkapan sondong adalah 20 jenis spesies termasuk beberapa jenis sampah yang juga ikut masuk kedalam kantong sondong. Jenis hasil tangkapan yang dibuang atau hasil tangkapan buangan selama penelitian 


\section{ZONA}

Jurnal Lingkungan

ISSN : 2502-6496 (Print)

Volume 4, No 2, Oktober 2019, p. 83-94 http://zona.pelantarpress.co.id

Tabel 8. Jenis hasil tangkapan buangan selama penelitian

\begin{tabular}{clc}
\hline No & \multicolumn{1}{c}{ Nama Lokal/Daerah } & Nama Latin/Ilmiah \\
\hline 1 & Blankas & Linulidae sp \\
2 & Ketam Kecil Laut & Scylla sp \\
3 & Anak Udang Nenek & Nephropidae $p$ \\
4 & Ikan Buntal & Tetraodon miurus \\
5 & Ikan Lepu & Pterois volitans \\
6 & Ikan Baji & Platycephalus indicus \\
7 & Udang Duri & Panulirus versicolor \\
8 & Siput Duri & Murex tribulus \\
9 & Anak Selidah & Cynoglossus lingua \\
10 & Anak Pari & Dasyatidae sp \\
11 & Laba-Laba Laut & Pantopoda sp \\
12 & Umang-Umang Lumpur & Paguroidea sp \\
13 & Bronot/Timun Laut & Holothuroidea sp \\
14 & Ketam Putih & Scylla sp \\
15 & Siput Laut & Gastropoda sp \\
16 & Anak Ikan Alu-Alu & Sphyraena sp \\
17 & Ikan Kitang & Scatophagus argus \\
18 & Ikan Kekek & Leiognatus equulus \\
19 & Anak Hiu Kucing & Scyliorhinidae sp \\
20 & Sampah & ( Ranting, Daun, Plastik, Kayu, \\
& & Sabut Kelapa, Buah Nipah, \\
& & Botol Minuman, Bungkus Snack) \\
& &
\end{tabular}

Menunjukkan bahwa sebanyak dua puluh jenis hasil tangkapan yang masuk kedalam kantong sondong akan dibuang kembali kelaut dalam keadaan hidup atau mati. Sesuai dengan pernyataan Eayrs (2005) menyatakan, hasil tangkapan yang dibuang adalah bagian dari hasil tangkapan sampingan yang dibuang atau dikembalikan ke laut dalam keadaan hidup atau mati. Hasil tangkapan sampingan yang dibuang terdiri dari spesies yang bernilai ekonomi rendah. Dalam pengertian yang luas hasil tangkapan sampingan yang dibuang mencakup semua hewan yang bukan merupakan sasaran utama dan benda-benda tidak hidup (sampah atau debris) yang tertangkap ketika melakukan operasi penangkapan.

Kepadatan relatif hasil tangkapan buangan (discard) atau HTB selama penelitian untuk blankas (Linulidae sp) 335 ekor dengan persentase 2,01\%, ketam kecil laut (Scylla sp) 2702 ekor dengan persentase 16,25\%, anak udang nenek (Nephropidae $s p$ ) 1336 ekor dengan persentase 8,03\%, ikan buntal (Tetraodon miurus) 592 ekor dengan persentase 3,56\%, ikan lepu (Pterois volitans) 1038 ekor dengan persentase 6,24\%, ikan baji (Platycephalus indicus) 94 ekor dengan persentase 0,57\%, udang duri (Panulirus versicolor) 2264 dengan persentase 13,62\%, siput duri (Murex tribulus) 1169 ekor dengan persentase 7,03\%, anak ikan selidah (Cynoglossus lingua) 279 ekor dengan persentase 1,68\%, anak ikan pari (Dasyatidae sp) 117 ekor dengan persentase 0,70\%, laba-laba laut (Pantropoda $s p$ ) 160 ekor dengan persentase 0,96\%, umang-umang (Paguroidea sp) 628 ekor dengan persentase 3,78\%, bronot/timun laut (Holothuroidea sp) 418 ekor dengan persentase 2,51\%, ketam putih (Scylla $s p$ ) 3150 ekor dengan persentase 18,94\%, siput (Gastropoda $s p$ ) 738 ekor dengan persentase 4,44\%, anak ikan alu-alu (Sphyraena sp) 69 ekor dengan persentase 0,41\%, ikan kitang (Scatophagus argus) 78 ekor dengan persentase 0,47\%, ikan kekek (Leiognatus equulus) 701 ekor dengan persentase $4,22 \%$, anak hiu kucing (Scyliorhinidae $s p$ ) 77 ekor dengan persentase $0,46 \%$, sampah (ranting, daun, plastik, kayu, sabut kelapa, buah nipah, botol minuman, bungkusan snak) 683 unit dengan persentase $4,11 \%$, jumlah total seluruh jenis spesies hasil tangkapan buangan atau yang dibuang 16.628 ekor 


\section{ZONA}

Jurnal Lingkungan

ISSN : 2502-6496 (Print)
Volume 4, No 2, Oktober 2019, p. 83-94

http://zona.pelantarpress.co.id

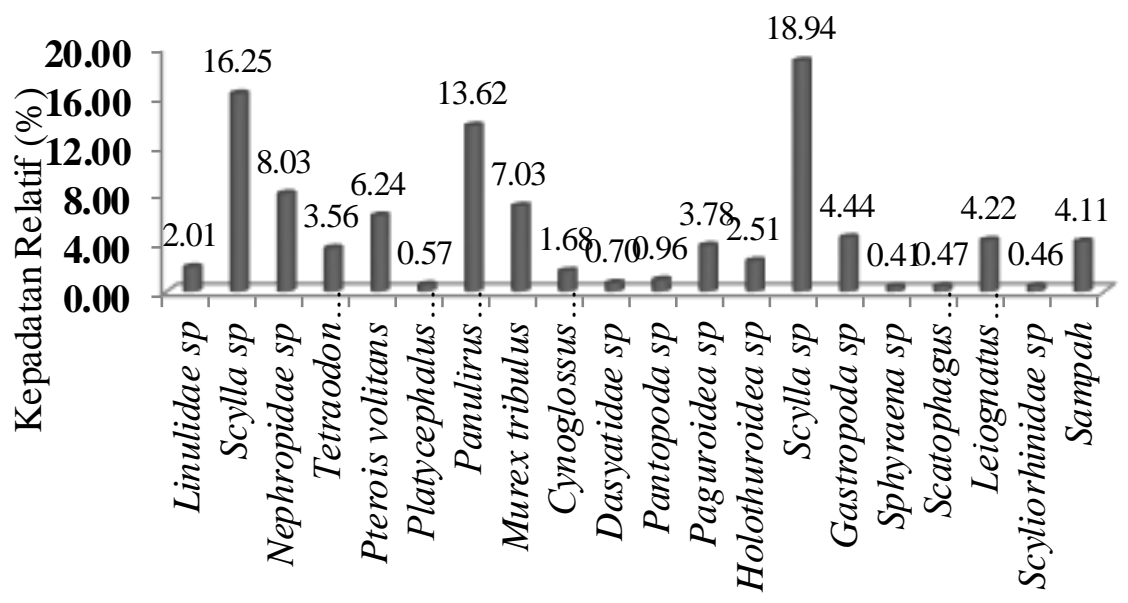

Gambar 4. Jumlah hasil tangkapan yang dibuang atau buangan yang diperoleh selama penelitian

Dari jumlah hasil tangkapan yang dibuang atau buangan yang diperoleh selama penelitian sebanyak dua puluh spesies, spesies yang mendominasi adalah ketam putih (Scylla $s p$ ) dengan persentase tertinggi yaitu $18,94 \%$ dengan jumlah spesies 3150 ekor dan jumlah spesies yang terendah persentasenya adalah anak ikan alu-alu (Sphyraena $s p$ ) yaitu 0,41\% dengan jumlah spesies 69 ekor dari jumlah total seluruh jenis spesies hasil tangkapan buangan 16.628 ekor. Persentase hasil tangkapan utama (HTU) berdasarkan jumlah (ekor) sebesar 38\% dengan jumlah 12.328 ekor, persentase hasil tangkapan sampingan (HTS) sebesar $11 \%$ dengan jumlah 3.453 ekor dan persentase hasil tangkapan buangan (HTB) sebesar 51\% dengan jumlah 16.628 ekor dari jumlah total seluruh hasil tangkapan 32.409 ekor. Hal ini menunjukkan bahwa persentase tertinggi hasil tangkapan berdasarkan jumlah (ekor) adalah hasil tangkapan buangan (HTB), selanjutnya adalah persentase hasil tangkapan utama (HTU) dan persentase terendah adalah hasil tangkapan sampingan (HTS).

Persentase hasil tangkapan utama (HTU) berdasarkan berat (kg) sebesar 22\% dengan jumlah berat $202,50 \mathrm{~kg}$, persentase hasil tangkapan sampingan (HTS) sebesar $6 \%$ dengan jumlah berat $60,60 \mathrm{~kg}$ dan persentase hasil tangkapan buangan (HTB) sebesar 72\% dengan jumlah berat $676,22 \mathrm{~kg}$ dari jumlah total seluruh berat hasil tangkapan 939,32 kg. Hal ini menunjukkan bahwa persentase tertinggi hasil tangkapan berdasarkan berat adalah hasil tangkapan buangan (HTB), selanjutnya adalah persentase hasil tangkapan utama (HTU) dan persentase terendah adalah hasil tangkapan sampingan (HTS). Untuk hasil tangkapan utama terdiri dari dua jenis udang yaitu udang tiger/windu (Penaeus monodon) dengan ukuran karapas berkisar 4-7 cm dengan panjang tubuh berkisar 7-13 cm dan untuk udang kuning/jerbung (Fenneropenaeus marguiensis) dengan ukuran karapas berkisar 3-5 cm dengan panjang tubuh berkisar 7-12 cm. Untuk ukuran hasil tangkapan utama selama penelitian.

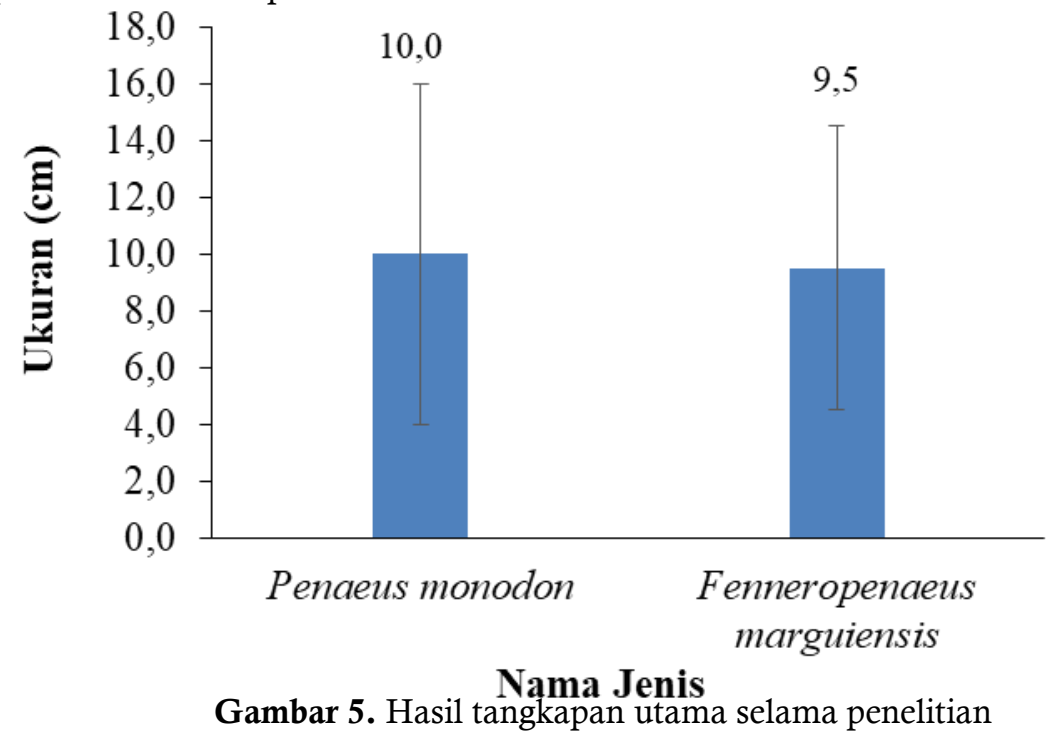




\section{ZONA}

Jurnal Lingkungan

ISSN : 2502-6496 (Print)

Volume 4, No 2, Oktober 2019, p. 83-94

http://zona.pelantarpress.co.id

\section{Hasil Tangkapan Sampingan}

Untuk hasil tangkapan sampingan terdiri dari 13 jenis yaitu Ikan Gelama (Nibea soldado) dengan ukuran hasil tangkapan yaitu panjang tubuh berkisar 12-13 cm, Ikan Selidah (Cynoglossus lingua) dengan panjang tubuh berkisar 16-20 cm, Udang Nenek/Mantis (Lysiosquila maculata) dengan panjang tubuh total berkisar $25-28 \mathrm{~cm}$, Ikan Duri (Hexanematichthys sagor) dengan panjang tubuh berkisar $13-15 \mathrm{~cm}$, Ikan Bilis (Engraulis japonicus) dengan panjang tubuh berkisar $10-12 \mathrm{~cm}$, Ikan Lomek (Ateoleopus japonics) dengan panjang tubuh berkisar $18-20 \mathrm{~cm}$, Ikan Biang (Ilisha elongate) dengan panjang tubuh berkisar 19 $20 \mathrm{~cm}$, Ikan Gonjeng (Thryssa mystax) dengan panjang tubuh berkisar $16-17 \mathrm{~cm}$, Ikan Senangin Pinang (Eleutheronema tetradactylum) dengan panjang tubuh berkisar $15-18 \mathrm{~cm}$, Ikan Timah (Aplocheilus panchax) panjang tubuh berkisar $25-27 \mathrm{~cm}$, Kerang (Tegillarca granosa) dengan ukuran tubuh berkisar antara $5-7$ $\mathrm{cm}$, Ikan Bawal (Pampus argenteus) dengan panjang tubuh berkisar antara $14-15 \mathrm{~cm}$ dan Ikan Tamban (Spratelloides gracilis) dengan ukuran tubuh berkisar $10-12 \mathrm{~cm}$.

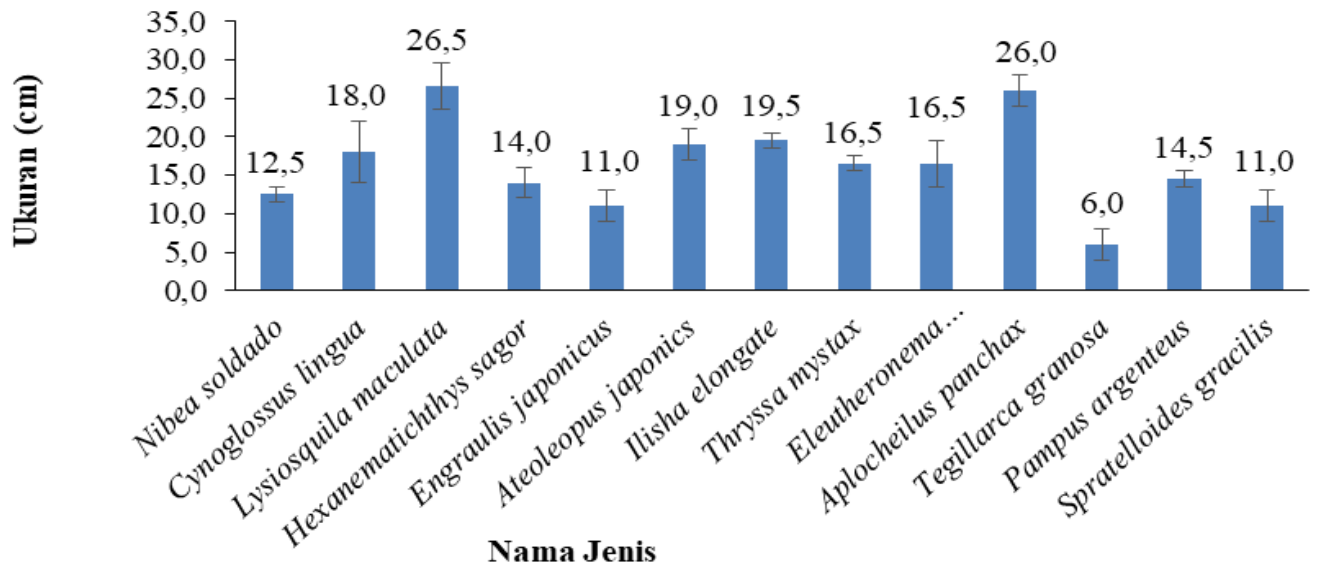

Gambar 6. Tangkapan Sampingan

Hasil tangkapan sampingan adalah bagian dari tangkapan nelayan yang tidak dikehendaki atau bukan sasaran utama. Hasil tangkapan sampingan dibuang ke laut atau dipergunakan untuk konsumsi manusia dan hewan. Tertangkapnya hasil tangkapan sampingan dapat menjadi ancaman bagi keanekaragaman spesies dan kesehatan lingkungan, sebab bagian dari tangkapan ini biasanya tidak diatur. Dalam pengertian yang luas hasil tangkapan sampingan mencakup semua hewan yang bukan merupakan sasaran utama dan benda-benda tidak hidup (sampah atau debris) yang tertangkap ketika melakukan operasi penangkapan.

\section{Hasil Tangkapan Buangan}

Untuk hasil tangkapan yang dibuang terdiri dari 19 jenis dengan ukuran tubuh yang terdiri dari Blankas (Linulidae $s p$ ) ukuran tubuh berkisar $12-20 \mathrm{~cm}$, Ketam Kecil Laut (Scylla $s p$ ) ukuran tubuh berkisar $8-14 \mathrm{~cm}$, Anak Udang Nenek (Nephropidae sp) dengan panjang tubuh berukuran berkisar $16-20$ $\mathrm{cm}$, Ikan Buntal (Tetraodon miurus) dengan ukuran panjang tubuh $10-12 \mathrm{~cm}$, Ikan Lepu (Pterois volitans) berukuran panjang tubuh sekitar $10-12 \mathrm{~cm}$, Ikan Senyenjeng (Ateoleopus sp) dengan ukuran panjang tubuh $12-15 \mathrm{~cm}$, Ikan Baji (Platycephalus indicus) dengan ukuran panjang tubuh berkisar $15-17 \mathrm{~cm}$, Udang Duri (Panulirus versicolor) dengan ukuran panjang tubuh berkisar $5-8 \mathrm{~cm}$. Siput Duri (Murex tribulus) dengan ukuran tubuh berkisar $7-10 \mathrm{~cm}$, Anak Ikan Pari (Dasyatidae sp) dengan ukuran tubuh $8-12 \mathrm{~cm}$, LabaLaba Laut (Pantopoda $s p$ ) ukuran tubuh berkisar $11-15 \mathrm{~cm}$, Umang Umang Lumpur (Paguroidea $s p$ ) ukuran tubuh berkisar $9-12 \mathrm{~cm}$, Bronot/Timun Laut (Holothuroidea $s p$ ) dengan ukuran tubuh berkisar $8-15 \mathrm{~cm}$, Ketam Putih (Scylla $s p$ ) dengan ukuran tubuh berkisar $9-12 \mathrm{~cm}$, Siput Laut (Gastropoda $s p$ ) ukuran tubuh berkisar 5-8 cm, Anak Alu-Alu (Sphyraena sp) dengan ukuran berkisar antara $20-30 \mathrm{~cm}$, Ikan Kitang (Scatophagus argus) ukuran yang tertangkap berkisar $5-7 \mathrm{~cm}$, Ikan Kekek (Leiognatus equulus) ukuran yang tertangkap berkisar $8-10 \mathrm{~cm}$ dan Anak Hiu Kucing (Scyliorhinidae sp) juga ada yang tertangkap dengan ukuran berkisar $20-30 \mathrm{~cm}$. 


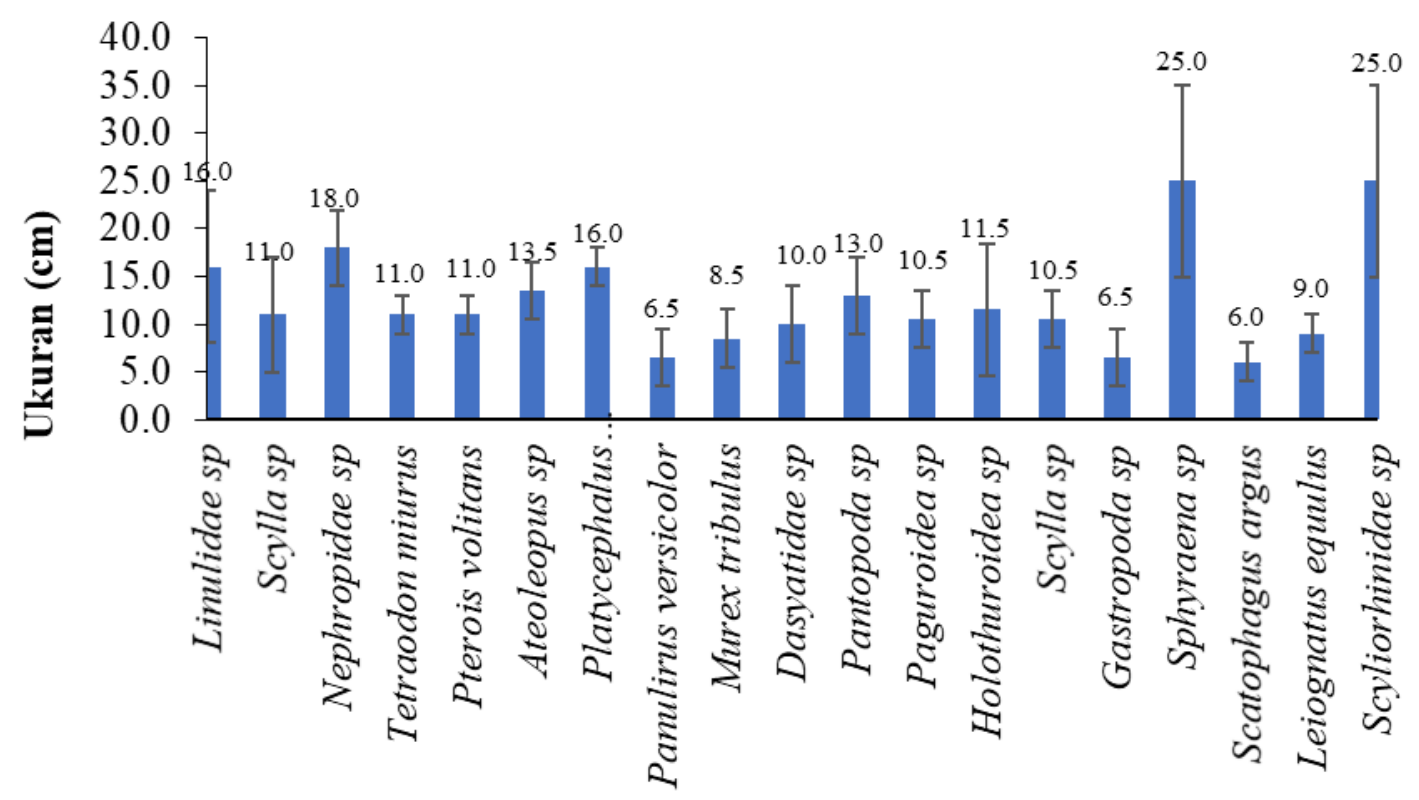

Nama Jenis Hasil Tangkapan Sampingan

Gambar 7. Tangkapan Buangan

Hasil tangkapan buangan tidak bernilai akan dibuang baik dalam keadaan hidup maupun dalam keadaan mati, hal ini memicu permasalahan konservasi yang serius dikarenakan terbuangnya sumber daya alam yang berharga serta menyebabkan populasi spesies terancam langka dan bahkan menjadi punah. Pengeksploitasian sumber daya laut secara lanjut akan mengakibatkan dampak perubahan terhadap ekosistem, keseluruhan jaringan trofik dan habitat. hasil tangkapan yang dibuang adalah bagian dari hasil tangkapan sampingan yang dibuang atau dikembalikan ke laut dalam keadaan hidup atau mati. Ini termasuk semua hewan dan benda tidak hidup yang tersangkut dengan alat tangkap tetapi tidak sampai di geladak kapal. Hasil tangkapan sampingan yang dibuang terdiri dari spesies yang bernilai ekonomi rendah, spesies ikan komersial yang kecil-kecil, ikan muda dan sampah dari dasar laut.

Dampak Sosial, Ekonomi dan Konflik yang Ditimbulkan Akibat Pengoperasian Alat Tangkap Sondong

Dalam pengoperasian alat tangkap sondong dampak sosial dan dampak ekonomi serta apakah pernah terjadi konflik di lingkungan perairan dalam penelitian ini dilakukan wawancara dan quisioner untuk nelayan alat tangkap sondong 15 orang, nelayan alat tangkap bukan sondong 5 orang, PPL/UPT Perikanan dan Kelautan 1 orang, Kepala Desa 5 orang dan Tokoh Masyarakat 5 orang

Hasil wawancara yang dilakukan selama penelitian terhadap (informan kunci) Pemerintah PPL/UPT Dinas Perikanan dan Kelautan Kecamatan Concong, Pemerintahan Desa dan Tokoh Masyarakat yaitu :

1. Secara resmi larangan penggunaan alat tangkap aktif menggunakan mesin telah dikeluarkan PeraturanMenteri Kelautan Dan Perikanan Republik Indonesia Nomor 2/Permen-Kp/2015 Tentang Larangan Penggunaan Alat Penangkapan Ikan Pukat Hela (Trawls) Dan Pukat Tarik (Seine Nets) Di Wilayah Pengelolaan Perikanan Negara Republik Indonesia. Namun ada kebijakan lokal bahwa untuk sondong selagi tidak ada konflik sosial dan lahan tetap diperbolehkan, karenan areal tangkapnya (fishing ground) terdiri dari dasar perairan berlumpur dan tidak terdapat karang serta tumbuhan laut (lamun dan rumput laut)

2. Perubahan lingkungan perairan akibat pengoperasaian alat tangkap sondong boleh dikatakan tidak ada, hanya saja kekeruhan yang meningkat disekitar area operasi sondong dalam waktu yang tidak terlalu lama karna ada pengaruh arus laut.

3. Kewenangan pemerintah setempat terhadap alat tangkap sondong selama tidak ada masalah dan mengganggu alat tangkap lain (gombang dan belat) boleh dioperasikan.

4. Dampak sosial (konflik) akibat pengoperasian alat tangkap sondong dapat dikatakan selama ini tidak ada, kecuali kalau mengganggu alat tangkap lain seperti (belat dan gombang). Pada Tahun 2015 pernah sekali terjadi masalah yaitu alat tangkap belat yang ditabrak. Tetapi cepat diselesaikan oleh pemerintah setempat, tokoh masyarakat, kepala desa dan tokeh.

5. Konflik areal penangkapan (fishing ground) antar nelayan juga dapat dikatakan tidak ada. Karna masingmasing alat tangkap punya areal tersendiri dan batasannya. Seperti nelayan tradisional Suku Duano yang mengumpulkan kerang dengan cara "menongkah" yaitu mengumpulkan kerang menggunakan 


\section{ZONA}

Jurnal Lingkungan

ISSN : 2502-6496 (Print)

tangan dengan alat bantu tongkah yang meluncur diatas lumpur. Kegiatan menongkah ini dilakukan pada kondisi perairan sedang surut. Alat tangkap belat dan gombang dioperasikan dengan memanfaatkan perairan dalam kondisi air pasang pada kedalaman tertentu.

Hasil wawancara yang dilakukan terhadap 5 orang bukan nelayan sondong (belat, gombang, tongkah) selama penelitian yaitu :

1. Tidak terganggu aktivitas penangkapan karna beroperasinya sondong. Hal ini disebabkan masingmasing saling menjaga dan beda area operasi penangkapan, kecuali ada yang dengan sengaja menabrak belat atau gombang

2. Rata-rata hasil laut sangat berkurang dibandingkan dahulu sekitar 10-15 tahun yang lalu

3. Hasil tangkapan secara umum memang berkurang tetapi bukan karena dioperasikannya sondong. Karena dahulunya sondong ini juga sudah ada tetapi hasil tangkapan lebih baik dari sekarang.

4. Hasil tangkapan tidak bertambah dan tidak berkurang karena pengoperasian sondong, nelayan sondong khususnya menangkap udang

5. Penghasilan tidak bertambah dan tidak berkurang karena beroperasinya sondong. Hal ini disebabkan hasil tangkapan dan alat tangkap yang berbeda

6. Rata-rata penghasilan perbulan berkisar Rp. 2.000 .000 - Rp. 3.000 .000

Hasil wawancara yang dilakukan terhadap 15 orang nelayan sondong selama penelitian yaitu :

1. Menyondong adalah merupakan pekerjaan utama pada musim nyondong tiba sekitar bulan Juni, Juli dan Agustus.

2. Rata-rata responden telah menggunakan alat tangkap sondong berkisar $5-20$ tahun.

3. Pekerjaan yang dilakukan selain menyondong adalah merawai dan menjaring apabila tidak turun menyondong.

4. Pendapatan yang diperoleh sekali menyondong berkisar antara Rp. 250.000 - Rp. 500.000 (belum dikurangi dengan $\mathrm{BBM}$ ).

5. Penghasilan yang didapat dari menyondong rata-rata berkisar Rp. $2.500 .000-\mathrm{Rp} .4 .000 .000$ per bulan.

6. Untuk tiga tahun terakhir rata-rata penghasilan dari menyondong sangat berkurang jika dibandingkan $10-15$ tahun yang lalu.

7. Belum pernah terjadi komplain oleh nelayan selain sondong ketika mengoperasikan alat tangkap sondong.

8. Pernah disosialisasikan oleh Dinas Perikanan dan Kelautan Kabupaten Indragiri Hilir pada Tahun 2016 tentang alat tangkap yang dilarang yang bersifat aktif, tetapi tidak langsung melarang sondong dioperasikan karna areal tangkapan (fishing ground) sondong di perairan laut Kecamatan Concong tidak terdapat karang dan tumbuhan air.

9. Untuk memenuhi kebutuhan sandang, pangan dan papan tergantung dari hasil melaut dan ketersediaan stok BBM serta kondisi mesin dan pompong

Dampak sosial, ekonomi dan konflik dari pengoperasian alat tangkap sondong dilingkungan perairan dapat dikatakan tidak ada. Secara sosial pengoperasian alat tangkap sondong diperairan lokasi penelitian dapat diterima, terjadinya penurunan penghasilan nelayan dan hasil tangkapan (ekonomi) secara umum bukan dikarenakan beroperasinya alat tangkap sondong, hal ini bisa saja disebabkan oleh semakin banyaknya alat tangkap yang beroperasi sehingga menyebabkan kelebihan tangkap (over fishing) atau ada faktor lain yang merusak habitat dan pencemaran diperairan. Dalam pengoperasian alat tangkap sondong dilokasi penelitian juga tidak menimbulkan konflik dengan kegiatan melaut lainnya. Menurut responden dan informan kunci, konflik akan terjadi apabila telah terganggunya alat tangkap lain yang sedang beroperasi atau aktivitas lain dilingkungan perairan.

\section{Perilaku Nelayan Dalam Pengoperasian Alat Tangkap Sondong yang protektif terhadap lingkungan (environmental protective behaviour)}

Dalam melakukan operasional alat tangkap sondong sebahagian besar dari nelayan yang dijadikan sampel dalam penelitian ini tidak lagi membuang sampah pada area tangkapan, dengan membawa bekal makanan dan minuman yang masih bisa dipakai ulang. Melakukan perlindungan wilayah tangkap untuk mencegah kompetisi yang tak sehat dengan sama-sama melarang alat tangkap yang dilarang oleh pemerintah. Nelayan ramah lingkungan yaitu yang menggunakan jaring insang hanyut, pancing tonda, pancing dasar, pancing cumi, rawai dasar, bubu labuh, rawai cucut dan purse seine.

\section{Prilaku yang destruktif terhadap lingkungan (enviromental destructive behaviour)}

Nelayan merusak lingkungan adalah nelayan yang menggunakan bahan peledak dan sianida dalam kegiatan penangkapan ikan. Sementara nelayan tidak ramah lingkungan adalah nelayan yang menggunakan kulambi/samba, jaring insang dasar, bagan perahu, pukat hiu, dan panah ikan. Untuk nelayan sampel dalam penelitian tidak ada yang menggunakan alat tangkap yang dilarang baik oleh pemerintah maupun kesepakatan para nelayan. 


\section{KESIMPULAN}

Dari hasil penelitian ini dapat disimpulkan sesuai dengan tujuan penelitian sebagai berikut :

1. Luas potensi kerusakan perairan laut akibat pengoperasian sondong berbanding lurus dengan lamanya waktu operasi, ukuran sondong, panjang sapuan dan jumlah hilir-mudik alat tangkap sondong. Semakin lama waktu operasi, semakin besar ukuran alat tangkap, semakin luas area sapuan dan semakin banyak jumlah setting (hilir-mudik) alat tangkap, semakin besar pula potensi kerusakan dasar perairan laut.

2. Hasil tangkapan buangan yang tidak bernilai akan dibuang baik dalam keadaan hidup maupun dalam keadaan mati menjadi limbah, hal ini memicu permasalahan konservasi yang serius dikarenakan terbuangnya sumber daya alam yang berharga serta menyebabkan populasi spesies terancam langka dan bahkan menjadi punah.

Dampak sosial, ekonomi dan konflik yang yang muncul di lingkungan perairan akibat pengoperasian alat tangkap sondong tidak ada. terjadinya penurunan penghasilan nelayan dan hasil tangkapan (ekonomi) secara umum hal ini bisa saja disebabkan oleh semakin banyaknya alat tangkap yang beroperasi sehingga menyebabkan kelebihan tangkap (over fishing) atau ada faktor lain yang merusak habitat dan pencemaran diperairan

\section{DAFTAR PUSTAKA}

Ahsan Mardjudo, 2011. Analisis Hasil Tangkapan Sampingan (By-Catch) Dalam Perikanan Pukat Pantai Jenis Krakat Di Teluk Kota Palu Sulawesi Tengah Jurnal Kiat Universitas Alkhairaat 1 (1):6-16

Eayrs, S. 2005. A Guide to Bycatch Reduction in Tropical Shrimp-Trawl Fisheries. Food and Agriculture Organization (FAO) of the United Nations, Rome

FAO. 1995. Code of Conduct for Responsible Fisheries. FAO Fishery Department. Rome. 24p.

Ghozali, I. 2005. Aplikasi Analisis Multivariat dengan Program SPSS. Universitas Diponegoro. Semarang

Megawati., I. Syofyan dan Syaifuddin. 2016. Analisis Usaha Penangkapan Sondong dan Pengembangannya di Kota Dumai. Fakultas Perikanan dan Kelautan, Universitas Riau, Pekanbaru

Menteri Kelautan dan Perikanan, 2016. Peraturan Menteri Kelautan dan Perikanan Republik Indonesia, Nomor 71/Permen-KP/2016 tentang Jalur Penangkapan Ikan dan Penempatan Alat Penangkapan Ikan di Wilayah Pengelolaan Perikanan Negara Republik Indonesia, Kementerian Kelautan dan Perikanan, Jakarta

Menteri Negara Lingkungan Hidup, 2004. Keputusan Menteri Negara Lingkungan Hidup Republik Indonesia, Nomor 51 Tahun 2004 tentang Baku Mutu Air Laut. Kementerian Lingkungan Hidup, Jakarta

Menteri Pertanian, 1976. Surat Keputusan Menteri Pertanian Republik Indonesia, Nomor 607/KPB/UM/1976 tentang Pengelolaan Sumber Daya Kelautan dan Perikanan. Kementerian Pertanian, Jakarta

2009. Undang - Undang Nomor 32 Tahun 2009 tentang Perlindungan dan Pengelolaan Lingkungan Hidup. Sekretariat Negara, Jakarta

Rainaldi., B. Zamdial.,dan Hartono.,D. (2017) Komposisi Hasil Tangkapan Sampingan (Bycatch) Perikanan Pukat Udang Skala Kecil Di Perairan Laut Pasar Bantal Kabupaten Mukomuko. Jurnal Enggano 2 (1): 101-114

Sugiyono, 2012. Metode Penelitian Kuantitatif, Kualitatif dan R\&D. Alfabeta, Bandung 